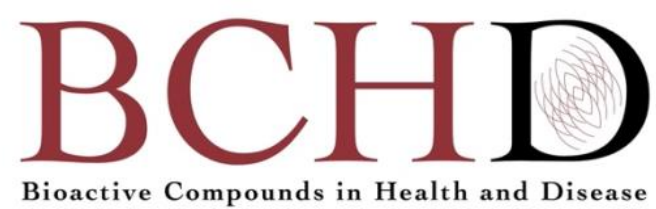

\title{
Innovative vegetables-processed cheese: II. high nutritional and functional attributes
}

\author{
Mohamed M. El-Loly*, Ashraf G. Mohamed, Eman S.A. Farahat
}

Dairy Department, Food Industries and Nutrition Research Institute, National Research Centre (NRC), 33 El-Buhouth St. (former El-Tahrir), El-Dokki, PO Box 12622, Giza, Egypt

*Corresponding Author: Mohamed El-Loly, Professor, Dairy Department, Food Industries and Nutrition Research Institute, National Research Centre (NRC), 33 El-Buhouth St. (former El-Tahrir), El-Dokki, PO Box 12622, Giza, Egypt.

Submission Date: January 7th, 2022 ; Acceptance Date: January 25th, 2022 ; Publication Date: January $28^{\text {th }}, 2022$

Please cite this article as: El-Loly M.M., Mohamed A.G., Farahat E.S.A. Innovative vegetables-processed cheese: II. High nutritional and functional attributes. Bioactive Compounds in Health and Disease 2022; 5(1): 13-32. DOI: https://www.doi.org/10.31989/bchd.v5i1.889

\begin{abstract}
Background: Foods not only aim to satisfy hunger and provide for essential nutritional needs, but they also improve the consumers' general health and prevent diseases related to nutrition. Nowadays, functional foods have seen rapid growth in the market driven by technological innovation and new product development. Our recent study produced a novel processed cheese using vegetables mixture that had a highly physicochemical composition and rheological and sensory characteristics.
\end{abstract}

Methods: This study was conducted to improve the nutritional and functional qualities of processed cheese using several vegetables (flavored-processed cheese, FPC) (mushrooms, dill, leeks, parsley, celery, green peas, green beans, squash, potatoes, and carrots) with ratios of $2.5,5,7.5$, and $10 \%$.

Results: Our data on nutritional values for FPC samples contain extra micro and macro-nutrient components, such as vitamins, minerals, antioxidants, amino acids, and unsaturated fatty acids, compared to the control cheese. Adding the vegetable mixture was accepted by the consumers and can contribute to the production and development of a new and safe type of processed cheese that has an excellent nutritional value, functional properties, and overall acceptability. Ratios of $5 \%$ and $7.5 \%$ were observed as the best samples. 
Conclusion: We recommend that vegetables should be used as a natural food additive for technological purposes. These are necessary sources of human health-promotion by nutritional and functional food properties of various dairy products.

Keywords: Processed cheese, vegetables, nutritional values, amino acids, fatty acids, minerals, vitamins, and antioxidants

\section{Processed Cheese from Vegetables}

\section{Vegetable Mixture}

mushrooms, dill, leeks, parsley, celery, green peas, green beans, squash, potato, carrot

\author{
Combination with Cheese \\ vegetables were added in \\ ratios of $2.5,5,7.5,10 \%$; \\ best results were seen with \\ ratios of 5 and $7.5 \%$
}

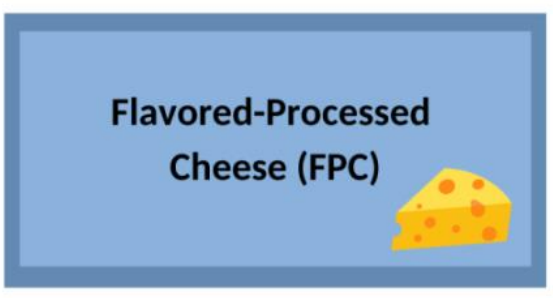

Positive Attributes of FPC

- FPC has increased nutritional quality with more vitamins, minerals, amino acids, and antioxidant compounds

- FPC samples were favored amongst all age groups

- The enhanced taste and aroma attracted many consumers

- Has many health benefits to advance health promotion due to their high phenolic compounds and high antioxidant capacity

CFFC 2022. This is an Open Access article distributed under the terms of the Creative Commons Attribution 4.0 License (http://creativecommons.org/licenses/by/4.0)

\section{INTRODUCTION}

Given the significant effect of the coronavirus on the physical and mental health of many people, there is a growing interest in eating foods that serve health-related purposes [1]. Many choose the organic system for old favorites, such as cheese, which remain a constant staple. There are various high-quality cheeses made by professional cheese makers. With some creativity, adding vegetables to cheese can be a great way to explore new flavors and textures of this novel product.

The food industry demands are related to increasing the healthy lifestyle and well-being of consumers, and bio-functional foods supplemented with plant-based ingredients play an important role in doing so. Many biotechnology companies have developed new dairy products as functional foods by adding bio-functional activities to human health and consumer acceptance [2]. A mixture of natural cheeses, dairy, and nondairy components can be added to make processed cheese. Several nondairy products were used, such as vegetables, fruit pulp or juices, mushrooms, oats, meat, egg protein, and wheat fiber [3]. Consuming vegetables and fruits can help fight inflammation and reduce the risk of many diseases, such as heart disease, strokes, digestive or eye problems, blood pressure. It also has a positive effect on blood sugar and cancer presentation [4-5]. Also, it is one 
of the most important health advancement policies due to its great content of phytonutrients, minerals, dietary fibers, and vitamins [6]. Most vegetables are rich in vitamins, minerals, and fiber, and low in calories [7].

The authors in a previous recent study (part I) Farahat et al. [8] produced a novel processed cheese using the same vegetable mixture that had a highly physicochemical composition and rheological and sensory characteristics. This work determines the possibility of creating and developing new healthy functional foods, such as flavored-processed cheese, using a mixture of many dried vegetables. It also evaluates its effect on the nutritional assessment of the resulting cheese.

Mushrooms (Lentinula edodes or Shiitake) belong to the fungal plant kingdom, categorized as a vegetable in the nutritional world (not technically a plant), and have a high source of bioactive therapeutic ingredients, along with many essential nutrients. They can potentiate the immune system as they stimulate anti-mutants and prevent the occurrence of tumors. For their benefits, mushrooms have been rated as food and medicine around the world for thousands of years [9-10]. Mushrooms are not only consumed as vegetables, but also as alternatives to active substances in health supplements and functional foods. They have been used as food and flavoring substances because of their unique and wonderful flavor. They are also low in energy, sugar, and fat, but rich in proteins, vitamins, minerals, and dietary fiber (non-starch polysaccharides). They also have many biologically active molecules that are a good source for human health. Several new value-added products contain mushrooms such as noodles, ketchup, biscuits, pickles, chips, soup powder, nuggets, and paste [11-14].

Mushrooms also contain a great source of vitamin $D$, most of the B-vitamin group, high-quality proteins, and essential amino acids. The essential USFA accounts for $72 \%$ of total fatty acids (TFA), where linoleic acid has been related to healthy food [15]. It contains polysaccharide and phenolic components, which have antioxidant activity and reduce the effect of oxidative damage because of their high free radical scavenging properties [16]. Additionally, the previous components make it an effective therapeutic food product for the fight against various degenerative diseases such as high cholesterol, acquired immunodeficiency syndrome (AIDS), cardiovascular disease, and cancer [17]. Mushrooms are more attractive as a beneficial food source for health or pharmaceutical development. They are effective for cardiovascular, hepatic, antidiuretic, hypolipidemic, immunomodulation, hypotensive, antithrombotic, antitumor, anti-inflammatory, antibacterial, antifungal, and antiviral issues [18].

Potatoes (Solanum tuberosum) have lower fat and unique nutritional values and phytochemical profiles (carotenoids, phenolic). They are also especially high in water-soluble vitamins $(B, C)$, minerals $(K, M g, M n)$, carbohydrates (polysaccharide starch), and dietary fibers. It is an important plant for preventing undernutrition, over-nutrition (heart diseases, obesity, diabetes), and many other diseases [19]. A recent study showed that potatoes are rich in fiber, which has a beneficial health effect for regulating appetite and gut metabolism [20].

Squash (Cucurbita pepevars) is an excellent source of vitamins $\left(A, E, B_{1}, 3,6\right)$, folate, pantothenic acid, $M n, K$, and dietary fiber. It has good nutritional value that makes it useful for digestion and blood pressure regulation, and reduces the risk of diabetes, obesity, and heart disease. Some vegetables and fruits, like squash, have a bright orange pigment due to the presence of beta-carotene that is an antioxidant. Other orange plant foods high in beta-carotene include carrots, apricots, sweet potato, pumpkin, cantaloupe, papayas, and broccoli [21]. Similarly, Cucurbita pepo is widely used as a food and folk medicine worldwide such as in pharmacology, chemical 
ingredients, and clinical uses. It is mainly known for its improvement in prostatic hyperplasia and urinary dysfunction. Also, many pharmacological studies have demonstrated benign prostatic hyperplasia, hepaticprotection, antimicrobial, anti-inflammatory, antidiabetic, antioxidant, antiulcer, and anticancer effects [22]. Likewise, pumpkin (a type of squash) was an excellent source of biologically active and nutritional compounds (vitamin C, minerals, $\alpha$, and $\beta$-carotene, dietary fiber, and lutein), which are vital to provide benefits for human health [23].

Carrots (Daucus carota) are considered one of the most common and vital root vegetables to human nutrition, which are high in biologically active components (carotenoids, dietary fiber), minerals, and vitamins. These components have many health benefits, such as lowering cholesterol and signs of premature aging, losing weight, protecting against cardiovascular disease and cancer, detoxifying the body, boosting the immune system, and improving digestion, skin health, and eye health [24-25]. Also, the consumption of carrots and its products is constantly increasing due to their rich natural source of antioxidants ( $\beta$-carotene), which have an anti-cancer activity $[24,26]$.

Green beans (Phaseolus vulgaris) are a functional food that promote good health because they contain high levels of a good source of biologically active ingredients (polyphenols, polysaccharides, and peptides), protein, fiber, minerals, and vitamins [27]. It is also a good source of the B vitamins group, carotenoids, and minerals, particularly $\mathrm{Mn}$ that has antioxidant capabilities, supports metabolism, and promotes wound healing and bone health. Additionally, it reduces the risk of heart disease and stroke because is low in sodium and has no cholesterol. It also helps in maintaining a healthy weight and contains several essential vitamins (folic acid) that prevent defects of congenital anomalies and neural tube [28-29]. In addition to containing a high level of antioxidants, it contains carotenoids and proteins which make it a real nutrition mine [30]. Further, beans help lower cholesterol and manage blood sugar through its carbohydrate content lowering the glycemic index [31].

Green peas (Pisum sativum) are relatively low in energy, rich in starch, and contain antioxidants, carotene, proteins, vitamins, minerals, oil, and cellulose; thus, it helps in treating and preventing some chronic diseases such as diabetes, heart disease, and cancer [32]. In addition to being high in vitamins and minerals, it provides lutein, zeaxanthin, and the carotenoid, phytonutrients, which promote vision and eye health [7].

Celery (Apium graveolens) is a bitter, aromatic herb, containing organic acids, vitamins, and minerals, used as a traditional medicinal food (indigestion, flatulence, antiinflammatory, anti-hypertension, and uterine tonic). The herbs, roots, and ripe seeds are used for treating kidney diseases, rheumatism, diuretic, stimulant, and carminative [28, 33]. It is also used for bowel regulation, gland stimulation, kidney and gallbladder stone prevention, diuretic, nervous agitation, anti-helminthic, exhaustion, appetite loss [34].

Leeks (Allium ampeloprasum var. kurrat) contain much higher values of phenolic organic sulfur components that contribute to its high flavor. They are also used as an anti-fungal, anti-atherosclerotic, and tumor inhibitor, and are an excellent source of flavonoids, glucosinolates, polysaccharides, and nitrates. These ingredients are rich in phenolic and biological antioxidants used as an alternative natural antioxidant source for applications in functional foods and nutraceuticals [35-36].

Dill (Anethum graveolens) has as a powerful antioxidant, antimicrobial, and antihypercholesterolaemic effect, and treats gastrointestinal diseases such as stomachic, antispasmodic, and carminative [37]. Since it also has strong antioxidant and immunological properties, it can be used for the 
applications of natural functional foods and pharmacology [38].

Parsley herb (Petroselinum crispum) has been used in folk medicine for many cases as a laxative [39], diuretic [40], and treatment of urinary tract infections [41]. It also reduces blood glucose [42] and contains a rich source of $\beta$-carotene, phenols, flavonoids, vitamins $(B, E, C)$, and minerals $[37,43]$. It is used as an herb of flavor in many foods [44] because of its powerful, aromatic scent.

Plants are popular in the daily diet due to their health benefits. Some of them are famous vegetables, such as celery, parsley, and carrots, while others are known for their medicinal and aromatic properties, such as dill, angelica, lovage, caraway, anise, fennel, cumin, and coriander [45]. Vegetable consumption protects against stroke, colorectal cancer, depression, hip fractures, and pancreatic diseases, while the fruits consumption protect against colon cancer, depression, and pancreatic diseases besides cardiovascular disease [46]. In a recent study, we observed the consumption of various vegetables used for preventing myocardial infarction [47].

\section{MATERIALS AND METHODS}

1.1. Raw materials: Vegetable selection, edible mushrooms, ras and cheddar cheeses were collected from a local market in Cairo, Egypt. Low-heat skim milk powder was obtained from a local market (Irish Dairy Council, Dublin, Ireland), emulsifying salts were obtained from Green Land (International Dairy and Food Company, $10^{\text {th }}$ Ramadan City, Egypt), and unsalted butter was obtained from Dina Farm in Sadat City, Egypt. The raw component composition used in the making of the processed cheese with vegetables has been shown in Table 1.

Table 1. The chemical composition (\%) of the ingredients used in the manufacture of processed cheese

\begin{tabular}{|l|c|c|c|c|c|c|c|c|}
\hline Ingredients & $\begin{array}{c}\text { Total } \\
\text { solids }\end{array}$ & $\begin{array}{c}\text { Total } \\
\text { protein }\end{array}$ & $\begin{array}{c}\text { Soluble } \\
\text { nitrogen }\end{array}$ & Fat & Ash & $\begin{array}{c}\text { Salt } \\
\text { (NaCl) }\end{array}$ & $\begin{array}{c}\text { Total } \\
\text { carbohydrates }\end{array}$ & $\begin{array}{c}\text { Fiber } \\
\text { Cheddar cheese }\end{array}$ \\
\hline Ras cheese & 54.00 & $25.50^{*}$ & 1.19 & 38.5 & 5.50 & 1.53 & ND & ND \\
\hline Skim milk powder & 95.00 & $37.13^{*}$ & 0.82 & 0.99 & 7.90 & ND & 47.67 & ND \\
\hline Unsalted butter & 84.00 & ND & ND & 82.00 & ND & ND & ND & ND \\
\hline $\begin{array}{l}\text { Several vegetables } \\
\text { powder blend }\end{array}$ & 96.00 & $22.80 * *$ & ND & 4.80 & 10.70 & ND & 31.07 & 26.61 \\
\hline
\end{tabular}

$*$ : Protein $\%=N \times 6.38, * *$ : Protein $\%=N \times 4.38$, ND: Not determined.

\subsection{Methods}

\subsubsection{Prepare a mixture of many vegetables: Many} vegetable types were selected to prepare one mixture as follows: carrots (Daucus carota), potatoes (Solanum tuberosum), squash (Cucurbita pepevars), green peas (Pisum sativum), green beans (Phaseolus vulgaris), celery (Apium graveolens), leeks (Allium ampeloprasum var. kurrat), parsley (Petroselinum crispum), dill (Anethum graveolens), and edible mushrooms (Lentinula edodes).
They have been cleaned and the outer peels have been removed, washed well, and placed at room temperature until completely dry. Once dry, we ground each type separately into a fine powder, then set them in sealed plastic bags and stored them in a dry place until use. We added $10 \mathrm{~g}$ of each and mixed them well to become one ingredient. Then they were used in flavored-processed cheese with ratios $2.5,5,7.5$, and $10 \%$. 


\subsubsection{Sample preparation of flavored-processed cheese}

(FPC) using vegetables powder mixture: FPC is prepared from a mixture of natural cheeses with different maturity degrees (old Cheddar, young Ras), other dairy products (skim milk powder, unsalted butter), nondairy products (emulsifying salts, flavor enhancers as dried vegetables mixture in ratios of $2.5,5.0,7.5,10 \%)$, and water. They are put into a pilot machine $(5-\mathrm{Kg}$ double-shell steam boiler) at NRC, Egypt, and prepared at $85-95^{\circ} \mathrm{C} / 15 \mathrm{~min}$ using direct injection steam at 1.5 bar pressure with continuous stirring. When the hot mass becomes homogenous, it is manually packaged into sterile $50 \mathrm{~mL}$ glass cups, covered with aluminum foil, and stored at refrigeration temperature until further use. The control sample consists of all ingredients without vegetables; three replicates were prepared for each formulation. Figure 1 showed the flow chart of processed cheese preparation, while Table 2 presented the different constituents used in FPC manufacture. Resultant FPC samples were assessed for their nutritional value [amino acids (AA), fatty acids (FA), vitamins, minerals, and antioxidants].

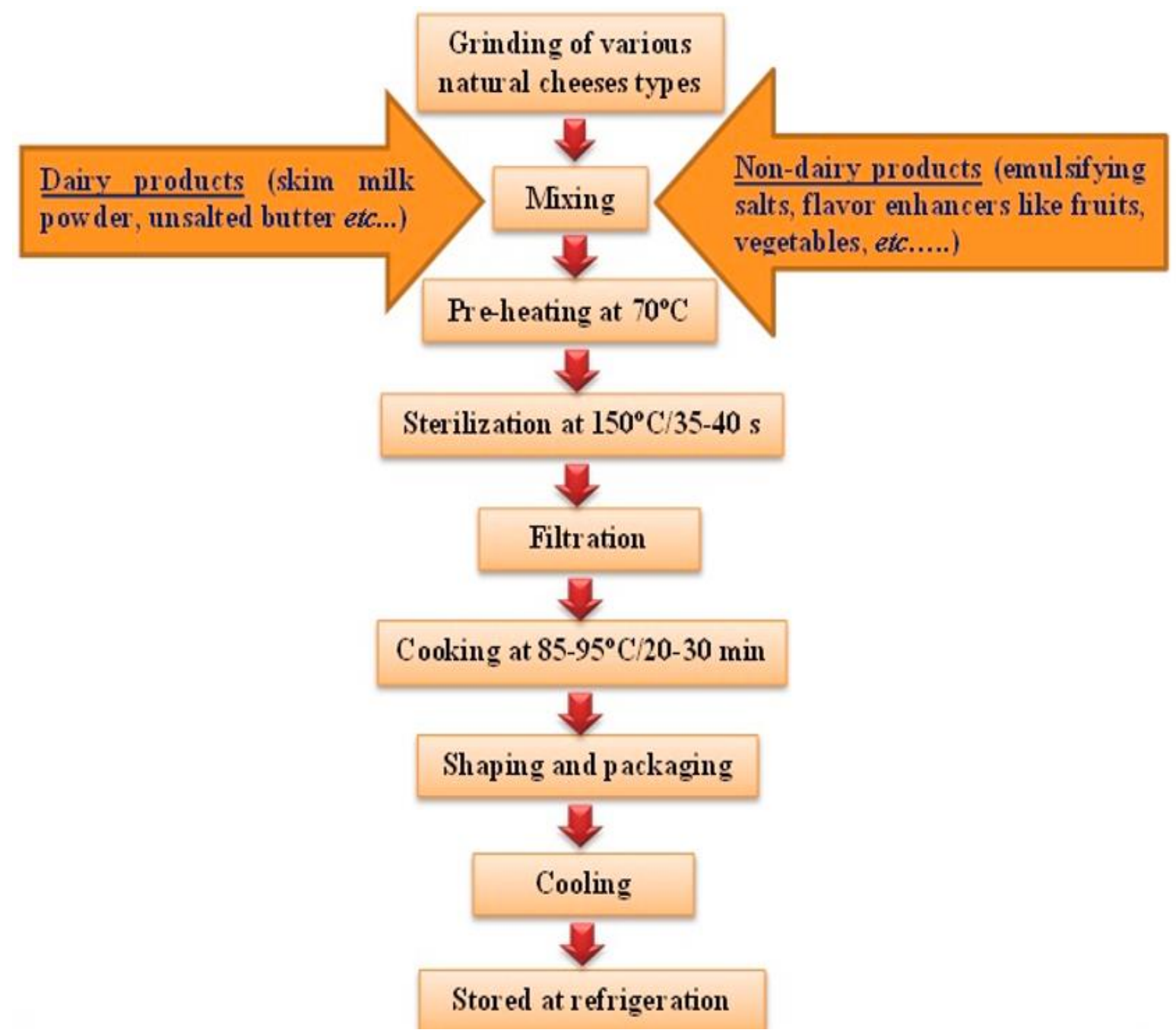

Figure 1. Schematic flowchart of processed cheese preparation. 
Table 2. Formulations of the ingredients used in the manufacture of FPC with several vegetables powder blend

\begin{tabular}{|c|c|c|c|c|c|}
\hline \multirow[t]{2}{*}{ Ingredients } & \multirow[t]{2}{*}{ Control } & \multicolumn{4}{|c|}{ Formulations with ratios of vegetables blend (\%) } \\
\hline & & $F_{1}(2.5)$ & $F_{2}(5.0)$ & $F_{3}(7.5)$ & $F_{4}(10)$ \\
\hline Cheddar Cheese & 12.80 & 12.80 & 12.80 & 12.80 & 12.80 \\
\hline Ras cheese & 38.44 & 38.44 & 38.44 & 38.44 & 38.44 \\
\hline Skim milk powder & 5.12 & 5.12 & 5.12 & 5.12 & 5.12 \\
\hline Unsalted butter & 10.26 & 10.26 & 10.26 & 10.26 & 10.26 \\
\hline Emulsifying salts & 2.5 & 2.5 & 2.5 & 2.5 & 2.5 \\
\hline Several vegetables powder blend & - & 2.50 & 5.00 & 7.5 & 10.00 \\
\hline Added water & 30.88 & 28.38 & 25.88 & 23.38 & 20.88 \\
\hline Total & 100 & 100 & 100 & 100 & 100 \\
\hline
\end{tabular}

\subsubsection{Analytical methods}

1.2.3.1. The nutritional values of FPC samples using vegetables powder mixture: The nutritional values (amino acids, fatty acids, vitamins, minerals, and antioxidants) of flavored processed cheese samples using vegetables mixture were estimated.

\subsection{Amino acid profile of FPC samples using} vegetables mixture: Amino acid profile analysis was conducted using Eppendorf-Biotronic LC 3000 amino acid analyzer (Eppendorf-Biotronic, Hamburg, Germany) [48].

\subsection{Fatty acid profile of FPC samples using} vegetables mixture: Fatty acid profile analysis was determined using gas-liquid chromatography (GLC Hewlett Packard 6890) [48].

\subsection{Vitamin level of FPC samples using} vegetables mixture: Fat-soluble vitamins $(A$ and $E)$ and water-soluble vitamins $\left(C, B_{1}, B_{2}, B_{3}\right.$, and $\left.B_{6}\right)$ were conducted using HPLC analysis method of [49].
1.2.3.1.4. Mineral level of FPC samples using vegetables mixture: The mineral content was determined by atomic absorption spectrophotometry [48].

1.2.3.1.5. Antioxidant activity of FPC samples using vegetables mixture: Antioxidants (free radical scavenging and total phenolic compounds) of flavored processed cheese samples using vegetables mixture were determined.

\subsection{Radical scavenging activity (RSA percent):} Antioxidants were determined as free radical scavenging activity according to [50] and expressed as percentage inhibition of the $\alpha$-diphenyl- $\beta$-picrylhydrazyl (DPPH) radical using the following equation:

RSA $\%=\frac{\text { Abs control }- \text { Abs sample }}{\text { Abs control }} \times 100$

Where: Abs control: The control reaction absorbance (blank with $0.1 \mathrm{ml}$ ethanol and $1.9 \mathrm{ml} \mathrm{DPPH})$. 
Abs sample: The sample reaction absorbance $(0.1 \mathrm{ml}$ sample diluted in ethanol and DPPH).

\subsection{Total phenolic compounds (TPC): TPC was} determined according to [51] using Folin-Ciocalteu reagent and expressed as milligram based on Gallic acid (GA) per 100g.

\subsubsection{Statistical analysis of FPC samples using} vegetables powder mixture: One-way analysis of variance (ANOVA) was performed using software [52]. Duncan's multiple comparison tests were selected to determine the significant differences among samples at $p \leq 0.05$. All experiments were performed in three replicates.

\section{RESULTS AND DISCUSSIONS}

Processed cheese is an important dairy product; it is easily produced and handled without the need for special conditions due to its high ability to preserve. It is gaining increasing popularity worldwide for its wide use of applications, diverse composition, and attractiveness to all ages for its pleasant flavor and its distinct texture and taste. There is a growing demand for healthy cheese, although there are still few studies available that address the use of vegetables and fruits for dairy fortification.

Recommendations on increasing the consumption of vegetables and fruits have become a global priority as they reduce the risks of cancer, cardiovascular disease, and early mortality. It is also an important component of a daily healthy diet because of its richness in antioxidants, vitamins, and minerals; lower energy (fat, sugars); and source of dietary fiber. It also improves digestive health and prevents weight gain, micronutrient deficiencies, obesity. Obesity is also a risk factor for noncommunicable diseases (some cancers, cardiovascular) and chronic diseases (i.e. diabetes) [53]. Moreover, it is one of the dairy products that is high in calcium, protein, and other nutrients as a balanced diet [54].

Several biotechnology companies have developed new dairy products as functional foods by adding biofunctional activities to meet human health and consumer acceptance [2]. It has become a tendency to search for dietary fiber as a nutrient source in food industries because of its physiological attributes [15].

Mushroom is a vegetable that contains most of the plant-food benefits, such as providing a good source of fiber and minerals (particularly $K$ ) and being low in energy, fat, and sugar. It also has health effects similar to other plant foods, because of decreasing cardiovascular disease [55]. Likewise, it has functional food components such as dietary fiber, proteins, amino acids, peptides, keto acids, poly-USFA, vitamins, minerals, and antioxidants like glutathione and selenium [56-57]. It is also not only valuable in a diet (as functional foods), but it contains some beneficial chemical materials that give it the biological effect of being high in protein but low in fat [58]. Manufacturers have greatly increased the importance of making processed cheese with health benefits (low salt and fat) [59].

\subsection{The nutritional values of FPC samples using} different vegetables powder mixture: Several nutrients are vital due to their biochemical activities for body nourishment, reproductive support, growth, and overall good health. Nutrients are divided into macro and micro- 
nutrients, where the $A A, F A$, and carbohydrates are classified as macro-nutrients that are consumed in relatively large quantities, while the vitamins and minerals are classified as micro-nutrients that are consumed in relatively smaller quantities. These nutrients are necessary for the body's processes to survive and stay healthy [60]. Besides, antioxidant compounds that provide phyto-nutrients are also essential. Vegetables are essential to a balanced diet due to their phytonutrients and nutraceutical compounds. They are known as protective foods, which are rich in carbohydrates, proteins, vitamins, and minerals, because they have biological activity against several chronic diseases [61].

\subsubsection{Amino acid profile of FPC samples using} vegetables mixture: Amino acids are one of the main macro-nutrient types, which represent the basic unit in protein formation. They are nutritionally classified as either essential amino acids (EAA) or non-essential amino acids (NEAA). Table 3 shows that the glutamic acid predominated in all processed cheese samples; it formed $19.18 \%$ of the total AA with an amount of $26.60 \mathrm{~g} / 100 \mathrm{~g}$ protein in the control samples. There was a significant difference between AA content of FPC and the control samples. Some EAA (leucine, histidine, threonine, and tryptophan) was significantly increased by the fortification-processed cheese; however, in contrast to other EAA (isoleucine, lysine, methionine, phenylalanine, and valine), it was significantly decreased with the highest ratio of fortification. The same manner was observed for NEAA (arginine, cysteine, alanine, aspartic, and tyrosine), which significantly increased, while the NEAA (glutamic, glycine, proline, and serine) significantly decreased $(p \leq 0.05)$. We can conclude that the enhancement of cheese using dried vegetables mixture can produce a complete product with EAA and NEAA needed for all human ages. Where the total AA was increased significantly with add advancement the vegetables mixture ratio of processed cheese samples it represents $138.68,147.31,155.97,165.38$, and 169.80 $\mathrm{g} / 100 \mathrm{~g}$ protein in control, $\mathrm{F}_{1}, \mathrm{~F}_{2}, \mathrm{~F}_{3}$, and $\mathrm{F}_{4}$, respectively.

NEAA can be synthesized enough in the body as substrates needed for protein synthesis; however, EAA cannot synthesize in the body, so it is taken from the diet. Some $A A$ is synthesized in the body in insufficient amounts, which is called semi-essential amino (histidine and arginine). Both EAA and NEAA should be consumed in the conventional "ideal protein" formulation of balanced diets to maximize protein development and enhanced human health [62]. Our study was in arrangement with that obtained by Khider et al. [15] found that fortification of processed cheese with dried mushrooms showed increases in leucine, histidine, arginine, cysteine, alanine, and tyrosine. It is an important source of natural flavor that stimulates the flavor of amino acids, especially glutamic acid [63]. Furthermore, the mushroom proteins have all nine EAA requisites by which humans can substitute for a meat diet. We can conclude from the obtained data that the enrichment of processed cheese with vegetables powder mixtures can produce complete product with EAA and NEAA needed for all human ages [64]. 
Table 3. Amino acid profiles of FPC samples using vegetables powder blend

\begin{tabular}{|c|c|c|c|c|c|}
\hline \multirow[t]{2}{*}{ Amino acids (g/100g protein) } & \multirow[t]{2}{*}{ Control } & \multicolumn{4}{|c|}{ Formulations with ratios of vegetables blend (\%) } \\
\hline & & $F_{1}(2.5)$ & $F_{2}(5.0)$ & $F_{3}(7.5)$ & $F_{4}(10)$ \\
\hline \multicolumn{6}{|l|}{ Essential amino acids (EAA): } \\
\hline Histidine & $3.84^{c}$ & $4.49 \mathrm{bc}$ & $5.14^{b}$ & $5.79 \mathrm{ab}$ & $6.44^{a}$ \\
\hline Isoleucine & $7.35^{a}$ & $6.90 \mathrm{ab}$ & $6.45^{a b}$ & $6.02^{a b}$ & $5.58^{b}$ \\
\hline Leucine & $12.45^{d}$ & $14.80^{c}$ & $17.15^{b}$ & $19.50^{a}$ & $21.85^{a}$ \\
\hline Lysine & $10.75^{a}$ & 10.35 ab & $9.96^{\mathrm{ab}}$ & $9.54^{b}$ & $9.17^{b}$ \\
\hline Methionine & $3.84^{a}$ & $3.45^{a b}$ & $2.81^{b}$ & $2.56^{b}$ & $2.31^{b}$ \\
\hline Phenylalanine & $7.35^{\mathrm{a}}$ & $6.25^{b}$ & $5.15^{b}$ & $4.05^{c}$ & $2.95^{d}$ \\
\hline Threonine & $4.69^{d}$ & $6.70^{c}$ & $8.71^{b}$ & $10.70^{a}$ & $12.73^{a}$ \\
\hline Tryptophan & $1.86^{b}$ & $2.10 \mathrm{ab}$ & $2.34^{a b}$ & $2.58^{a}$ & $2.82^{a}$ \\
\hline Valine & $9.05^{a}$ & $8.20^{a}$ & $7.35^{b}$ & $6.51^{b c}$ & $5.65^{c}$ \\
\hline Total EAA & $61.18^{d}$ & $63.24^{c}$ & $65.06^{b}$ & $67.25^{a}$ & $69.50^{a}$ \\
\hline \multicolumn{6}{|c|}{ Non-essential amino acids (NEAA): } \\
\hline Alanine & $4.30^{\mathrm{e}}$ & $6.60^{d}$ & $8.90^{c}$ & $11.21^{b}$ & $13.50^{a}$ \\
\hline Arginine & $4.30^{d}$ & $6.30^{c}$ & $8.02^{b}$ & $10.05^{a}$ & $10.07^{a}$ \\
\hline Aspartic & $9.62^{d}$ & $11.67^{c}$ & $14.22^{b}$ & $16.77^{a}$ & $16.37^{a}$ \\
\hline Cysteine & $0.49^{b}$ & $0.70 \mathrm{ab}$ & $0.91^{a b}$ & $1.12^{a}$ & $1.32^{a}$ \\
\hline Glutamic & $26.60^{a}$ & $24.30^{b}$ & $22.15^{c}$ & $20.05^{d}$ & $18.00^{\mathrm{e}}$ \\
\hline Glycine & $2.77^{a}$ & $2.50^{a b}$ & $2.23^{a b}$ & $1.97^{a b}$ & $1.69^{b}$ \\
\hline Proline & $14.15^{\mathrm{e}}$ & $15.80^{d}$ & $17.45^{c}$ & $19.10^{b}$ & $20.75^{a}$ \\
\hline Serine & $7.92^{c}$ & $7.30 \mathrm{bc}$ & $6.58^{b}$ & $5.86^{a b}$ & $5.15^{a}$ \\
\hline Tyrosine & $7.35^{e}$ & $8.90^{d}$ & $10.45^{c}$ & $12.00^{b}$ & $13.45^{a}$ \\
\hline Total NEAA & $77.50^{d}$ & $84.07^{c}$ & $90.91^{b}$ & $98.13^{a}$ & $100.30^{a}$ \\
\hline Total amino acids & $138.68^{d}$ & $147.31^{c}$ & $155.97^{b}$ & $165.38^{a}$ & $169.80^{a}$ \\
\hline
\end{tabular}

Values within a row having different superscripts differ significantly $(p \leq 0.05)$.

\subsubsection{Fatty acid profile of FPC samples using} vegetables powder mixture: Fatty acids are one of the main macro-nutrient types that play an important role in human life and nutrition, especially USFA that plays a role in the management and prevention of blood pressure levels, triglyceride levels, and cardiovascular diseases. Likewise, saturated fatty acids (SFA) exist in large quantities in foods of animal origin. They are linked to increasing triglycerides levels in the blood, and cause hypertension [65]. Table 4 shows that the short-chain SFA (butyric, caprylic, and capric acids) had no significant decrease in FPC samples compared to the control sample.
Also, both myristic and myristoleic acids had decreased in FPC samples but were significantly more decreased than the control sample. Conversely, palmitic, stearic, oleic, linoleic, and $\alpha$-linolenic acids were increased significantly in FPC with higher ratios of dried vegetables mixture. The SFA were reduced, while USFA (oleic, linoleic and $\alpha$-linolenic) were significantly higher $(p \leq 0.05)$ than the control sample. It was confirmed that mushrooms and vegetables could be a remarkable source of essential USFA due to the high level of USFA in mushroom and leafy vegetables. 
Table 4. Fatty acid profiles of FPC samples using vegetables powder blend

\begin{tabular}{|c|c|c|c|c|c|}
\hline \multirow[t]{2}{*}{ Fatty acids (g/100 g fat) } & \multirow[t]{2}{*}{ Control } & \multicolumn{4}{|c|}{ Formulations with ratios of vegetables blend (\%) } \\
\hline & & $F_{1}(2.5)$ & $F_{2}(5.0)$ & $F_{3}(7.5)$ & $F_{4}(10)$ \\
\hline \multicolumn{6}{|l|}{ Saturated fatty acids: } \\
\hline Butyric $\left(\mathrm{C}_{4: 0}\right)$ & 7.39 a & $7.35^{a}$ & $7.31^{a}$ & $7.27^{\mathrm{a}}$ & $7.23^{a}$ \\
\hline Caproic $\left(\mathrm{C}_{6: 0}\right)$ & $12.13^{a}$ & $12.10^{\mathrm{a}}$ & 12.07 a & 12.04 a & $12.02^{a}$ \\
\hline Caprylic $\left(\mathrm{C}_{8: 0}\right)$ & $9.58^{a}$ & 9.53 a & $9.48^{\text {a }}$ & $9.45^{a}$ & 9.41 a \\
\hline Capric $\left(\mathrm{C}_{10: 0}\right)$ & 13.67 a & $13.62^{a}$ & $13.57^{a}$ & $13.52^{a}$ & $13.47^{\mathrm{a}}$ \\
\hline Lauric $\left(\mathrm{C}_{12: 0}\right)$ & $7.30^{a}$ & 7.31 a & 7.32 a & 7.33 a & $7.34^{a}$ \\
\hline Myristic $\left(C_{14: 0}\right)$ & 22.28 a & $21.10^{b}$ & $19.92^{c}$ & $18.74^{c}$ & $17.56^{d}$ \\
\hline Palmitic $\left(C_{16: 0}\right)$ & $63.35^{d}$ & $66.29^{c}$ & $69.23^{b}$ & 72.17 a & $75.11^{a}$ \\
\hline Stearic $\left(C_{18: 0}\right)$ & $20.13^{b}$ & $20.43^{b}$ & $20.73 \mathrm{ab}$ & $21.03^{a b}$ & $21.33^{a}$ \\
\hline \multicolumn{6}{|c|}{ Mono-unsaturated fatty acids: } \\
\hline Myristoleic $\left(C_{14: 1}\right) n-5$ & $3.27^{a}$ & $2.91 \mathrm{ab}$ & $2.55^{a b}$ & $2.19^{b}$ & $1.83^{b}$ \\
\hline Palmitoleic $\left(C_{16: 1}\right) n-7$ & $4.76^{a}$ & $4.91^{\mathrm{a}}$ & $5.06^{\text {a }}$ & $5.21^{a}$ & $5.36^{a}$ \\
\hline Oleic $\left(C_{18: 1}\right), n-9$ & $48.07^{b}$ & $48.49^{b}$ & $4891^{\mathrm{ab}}$ & $49.33^{a b}$ & $49.75^{a}$ \\
\hline Cadoleic $\left(C_{20: 1}\right) n-11$ & $2.52^{\text {a }}$ & $2.42^{\mathrm{a}}$ & $2.33^{a}$ & $2.23^{a}$ & $2.14^{\mathrm{a}}$ \\
\hline \multicolumn{6}{|c|}{ Poly-unsaturated Fatty Acids: } \\
\hline Linoleic $\left(C_{18: 2}\right) n-6$ & $4.74 \mathrm{e}$ & $8.47^{d}$ & $12.71^{c}$ & $16.92^{b}$ & $21.14^{a}$ \\
\hline$\alpha$-Linolenic $\left(C_{18: 3}\right) n-3$ & $1.73^{\mathrm{e}}$ & $10.91^{d}$ & $15.75^{c}$ & $6.67^{b}$ & $20.58^{a}$ \\
\hline Unknown & $5.34^{\mathrm{a}}$ & $5.40^{a}$ & $5.46^{a}$ & $5.52^{a}$ & $5.58^{a}$ \\
\hline Total fatty acids (TFA) & $226.26^{d}$ & $236.40^{c}$ & $247.56^{b}$ & $258.70^{a}$ & $269.85^{a}$ \\
\hline
\end{tabular}

Values within a row having different superscripts differ significantly $(p \leq 0.05)$.

The fortification of the dried vegetables mixture induced various changes in the FA profile of all FPC samples, where little variations were recorded at lower values around short-chain (non-significant slightly decreased than control) and most mono-USFA (up and down than control). While noticeable great changes were observed in long-chain poly-USFA (especially linoleic acid and $\alpha$-linoleic acid), it had a significant higher increase in all of the FPC samples than in the control.

Our achieved results (Table 4) for the fatty acid profiles of FPC samples are in agreement with what was [65] reported that processed cheese with peanuts showed significant increases in oleic, linoleic, and $\alpha$ linolenic levels than the control sample. Similar results were obtained previously regarding the SFA and USFA levels of the soft cheese enhanced with mushrooms [66].
Also, mushrooms had trace amounts of fats with linoleic acid, compared to protein and carbohydrates, which makes it an ideal food to maintain the health of the cardiovascular system. Otherwise, the FPC samples contained a lower value of mono-USFA, but also a higher content of poly-USFA than the control sample, due to the higher contribution of linoleic acid [67]. This observation was compatibly with what we [68] established, that the mushroom has higher linoleic acid level and is a significant factor as a healthy food.

\subsubsection{Vitamin levels of FPC samples using vegetables} powder mixture: Vitamins and minerals are two of the main micro-nutrient types that the body requires to survive and function. Vitamins are organic composites necessary for proper bodily function and are classified as 
either soluble in water or fat. Fat-soluble vitamins (A, D, $\mathrm{E}$, and $\mathrm{K}$ ) can be absorbed, transported, and stored in body fat. Water-soluble vitamins ( $\mathrm{C}$ and B-complex) cannot be stored in the body because over ingestion results in the vitamins being dissolved in water and eliminated through human fluids such as sweating and urine, so they need to be renewed daily [69-70].

In the last decade, intake of vitamins has increased because of their vital role in raising the immunity of the human body and preventing health problems through their biochemical activities. Fat-soluble vitamins are absorbed and transported from consumed fat, and excess of these vitamins is stored in the liver and other parts of the body. Vitamin A affects enhancing eye vision, formatting blood cells, and improving immunity and growth, whether in carrots, green leafy vegetables, potatoes, squash, or dairy products. Vitamin E affects blood vessels, immunity, and effective antioxidants, and is present in dairy products, cereals, vegetable oils, and peanuts. Water-soluble vitamins are unnatural substances stored in high amounts in the human body, making them necessary for daily intake [71].

Table 5. Vitamin, mineral, and antioxidant levels of FPC samples using vegetables powder blend

\begin{tabular}{|c|c|c|c|c|c|}
\hline \multirow[t]{2}{*}{ Components } & \multirow[t]{2}{*}{ Control } & \multicolumn{4}{|c|}{ Formulations with ratios of vegetables blend (\%) } \\
\hline & & $F_{1}(2.5)$ & $F_{2}(5.0)$ & $F_{3}(7.5)$ & $F_{4}(10)$ \\
\hline \multicolumn{6}{|c|}{$\underline{\text { Vitamins }}$} \\
\hline \multicolumn{6}{|l|}{ Fat-soluble $(\mu \mathrm{g} / 100 \mathrm{~g}$ fat): } \\
\hline A (as Carotene) & $7.41^{d}$ & $7.78^{d}$ & $8.16^{c}$ & $8.53^{b}$ & $8.90^{a}$ \\
\hline A (as Retinol) & $3.69^{d}$ & $3.88^{c}$ & $4.07^{b}$ & $4.25^{a}$ & $4.44^{\mathrm{a}}$ \\
\hline E ( $\alpha$-tocopherol) & $2.50^{\mathrm{a}}$ & $2.46^{a}$ & $2.43^{a}$ & $2.39^{a}$ & $2.36^{a}$ \\
\hline \multicolumn{6}{|l|}{ Water-soluble (mg/100 g): } \\
\hline C (Ascorbic acid) & $1.24^{\mathrm{e}}$ & $3.51^{d}$ & $5.73^{c}$ & $7.21^{b}$ & $10.50^{a}$ \\
\hline $\mathrm{B}_{1}$ (Thiamin) & $1.11^{\mathrm{e}}$ & $1.86^{d}$ & $3.29^{c}$ & $4.46^{b}$ & $5.61^{\mathrm{a}}$ \\
\hline$B_{2}$ (Riboflavin) & $0.91^{d}$ & $1.90^{\mathrm{cd}}$ & $2.50^{c}$ & $3.29^{b}$ & $5.42^{a}$ \\
\hline $\mathrm{B}_{3}$ (Niacin) & $0.91^{d}$ & $1.22^{d}$ & $2.54^{c}$ & $4.86^{b}$ & $6.18^{a}$ \\
\hline $\mathrm{B}_{6}$ (Pyridoxine) & $0.71^{c}$ & $1.39^{c}$ & $2.37^{b}$ & $3.29^{b}$ & $4.47^{a}$ \\
\hline \multicolumn{6}{|c|}{ Minerals } \\
\hline \multicolumn{6}{|l|}{ Major elements $(\mathrm{mg} / 100 \mathrm{~g})$ : } \\
\hline Calcium (Ca) & $526.3^{a}$ & $490.1^{b}$ & $450.3^{c}$ & $411.7^{d}$ & $375.3^{e}$ \\
\hline Sodium (Na) & $535.2^{a}$ & $496.1^{b}$ & $457.1^{c}$ & $418.0^{d}$ & $379.3^{\mathrm{e}}$ \\
\hline Phosphorous (P) & $571.6^{a}$ & $431.3^{b}$ & $391.0^{c}$ & $350.7^{d}$ & $310.4 \mathrm{e}$ \\
\hline Potassium (K) & $72.2^{\mathrm{e}}$ & $99.5^{d}$ & $127.7^{c}$ & $154.3^{b}$ & $189.6^{a}$ \\
\hline Magnesium (Mg) & $19.4^{b}$ & $21.2^{b}$ & $23.0^{\mathrm{ab}}$ & $24.6^{a b}$ & $26.6^{a}$ \\
\hline $\mathrm{Na} / \mathrm{K}$ ratio & $7.41^{a}$ & $4.98^{a b}$ & $3.58 \mathrm{bc}$ & $2.70^{c}$ & $1.99^{c}$ \\
\hline \multicolumn{6}{|l|}{ Trace elements (ppm): } \\
\hline Manganese (Mn) & $0.357^{d}$ & $0.981^{c}$ & $1.213^{c}$ & $2.151^{b}$ & $3.083^{a}$ \\
\hline Copper (Cu) & $0.188^{a}$ & $0.216^{b}$ & $0.249^{c}$ & $0.285^{d}$ & $0.317^{\mathrm{e}}$ \\
\hline $\operatorname{Zinc}(Z n)$ & $0.184^{\mathrm{a}}$ & $0.126^{a}$ & $0.118^{a b}$ & $0.109^{b}$ & $0.101^{b}$ \\
\hline Iron (Fe) & $0.112^{a}$ & $14.82 \mathrm{bc}$ & $18.42^{b}$ & $21.92 \mathrm{ab}$ & $25.93^{a}$ \\
\hline Selenium (Se) & ND & $0.05^{a}$ & $1.10^{\mathrm{b}}$ & $1.40^{\mathrm{b}}$ & $1.90^{\mathrm{b}}$ \\
\hline \multicolumn{6}{|c|}{ Antioxidants } \\
\hline Radical scavenging activity (RSA \%) & $9.33^{\text {a }}$ & $34.48^{b}$ & $68.73^{c}$ & $86.04 d$ & 106.23 e \\
\hline $\begin{array}{l}\text { Total phenolic compounds (TPC mg/100g } \\
\text { based on Gallic acid) }\end{array}$ & $7.81^{a}$ & $114.01 \mathrm{~b}$ & $163.31^{c}$ & $199.12^{d}$ & $238.95^{e}$ \\
\hline
\end{tabular}

Values within a row having different superscripts differ significantly $(p \leq 0.05)$. 
As shown in Table 5, vitamins $A$ and $E$ represent two of the fat-soluble groups. Vitamin A (either in carotene or retinol) gradually increased with by increasing the vegetables mixture ratio in FPC samples compared to control cheese; carotene was valued twice as high as retinol. However, in reverse, vitamin E ( $\alpha$-tocopherol) had not significantly decreased in FPC samples compared to the control cheese. Similarly, the same trend occurred in the water-soluble vitamin group, where vitamin C gradually increased and was significantly higher in FPC samples than the control one. Dairy products are poor sources of vitamin $\mathrm{C}$ because of that, but the vegetables are a considerably rich source for it. Also, vitamin B complex $\left(B_{1}, 2,3,6\right)$ levels were significantly higher in FPC samples related to control cheese. Moreover, illustrated in the same Table 5, vitamin A is an essential fat-soluble micronutrient and gradually increased by increasing ratios of the vegetable mixture of FPC samples compared to the control cheese. It was significantly higher due to some carotenoids found in plants ( $\alpha$-carotene, $\beta$ carotene, and $\beta$-cryptoxanthine) that were converted to vitamin A using enzymatic procedure [72]. Our data also increased in riboflavin and niacin because of the high amount of mushrooms in these ingredients [13]. Vitamins ( $\mathrm{C}$ and $\mathrm{E}$ ) and carotenoids are known together as antioxidant vitamins, which act individually or collectively to prevent oxidative reactions causing many degenerative diseases like cancer, cardiovascular diseases, and cataracts [73]. Our obtained data are in accordance with [44, 74].

\subsubsection{Mineral levels of FPC samples using vegetables}

powder mixture: Minerals and vitamins are two of the main micro-nutrient types that the body requires to survive and stay healthy. Minerals are substances that the body cannot manufacture but are necessary to form healthy bones and teeth and regulate many vital body processes. As presented in Table 5, the $\mathrm{K}, \mathrm{Mg}$, Se, and Fe values of FPC samples were higher $(P \leq 0.05)$ than the control sample due to high mineral levels in the added vegetables mixture. Mushroom also had the highest trace mineral, (Se), content for thyroid function and as a key antioxidant [10]. These elements were gradually increased by increasing fortification ratios. In contrast, calcium, sodium, phosphorous, and zinc levels were decreased by increasing the fortified ratios compared to the control cheese. Furthermore, there is an increase in $\mathrm{K}$ with low $\mathrm{Na}$ levels in the FPC samples by increasing fortification ratios with the vegetable's mixture. In the reverse, reducing $\mathrm{K}$ is done by decreasing in $\mathrm{Na} / \mathrm{K}$ ratio. This produced healthier processed cheese due to the strong relationship between these elements' levels and high blood pressure in humans. Our finding is compatible with [75], indicating that $\mathrm{K}$ reduces both diastolic and systolic blood pressure, as well as decreases risk factors of heart diseases and hypertension decreased when increasing $\mathrm{K}$ and decreasing the $\mathrm{Na} / \mathrm{K}$ ratio.

The proper K-care is an essential element of recent health nutrition, thus its level in food is also a factor of medical importance [58]. Our data agreed with this author who found that mushrooms are not only valuable foods (functional foods), but they contain a useful chemical composition (high levels of $\mathrm{K}$ and $\mathrm{P}$, low $\mathrm{Na}$ content, large amounts of some microelements) [58]. Moreover, they have a double benefit of low $\mathrm{Na}$ and more $\mathrm{K}$ and Fe than most foods [76]. The higher the $\mathrm{Na} / \mathrm{K}$ ratio, the greater the chance of death from cardiovascular disease, a heart attack, or other reasons [77]. We conclude that results have been obtained for the production and development of a new dairy product of processed cheese. The cheese has health benefits for people of all ages because of its added vegetable mixture. The mixture has health-promoting nutritional and functional components as functional foods. Likewise, it achieved many goals. The first accomplishment was it has higher Fe levels than the normal cheese, and the 
second goal it achieved was it has a lower $\mathrm{Na} / \mathrm{K}$ ratio. These results were similar to the findings with $[74,78]$. We later found that the enrichment of the cheese with broccoli increased $\mathrm{K}, \mathrm{Mg}$, Zn, and Fe levels, whereas the Ca level was lower than control cheese. Furthermore, Fe is an essential mineral element and an important component of proteins involved in oxygen transport and metabolism [79]. Iron plays a major role in the formation of hemoglobin; oxidation of fats, proteins, and carbohydrates; and preservation of the normal function of the central nervous system [80]. Cu is an important cofactor for many major enzyme systems, while Zn (an essential trace element) contributes to normal growth and development [81].

\subsubsection{Antioxidant activities of FPC samples using} vegetables powder mixture: Antioxidants are molecules that can prevent the oxidation of proteins, carbohydrates, fats, and nucleic acids in organisms, and have attracted considerable attention as potential compounds (free radical scavenging activity and phenolic).

Foods classified as functional foods contain components that provide nutrients essential for good health, such as vegetables and fruits as good sources of antioxidants. This is beyond usual nutrients such as vitamins, minerals, anthocyanin, flavonoids, and phenolic acids. So, consumers are now increasingly demanding healthy foods. Of the 10.3 million new cancers diagnosed worldwide each year, up to $2 / 3$ result from nutritional factors and lifestyle. Diets rich in vegetables and fruits reduce the risk of many cancers and other degenerative diseases. Vegetables and fruits contain many phytonutrients that have antioxidant activities, which plays an important role in health benefits. Carrots and tomatoes contain high levels of $\beta$-carotene and lycopene in order. Antioxidants are compounds (free radical scavenging activity and phenolic) that can prevent oxidative-stress-related diseases, balance or inhibit oxidation degradation of various substances by reducing oxygen content and prevent chain initiation by scavenging premier radicals such as hydroxyl radicals.

Vegetables are a powerful source of main antioxidants and home nutrition, such as vitamins (A, C, $E$, and $K$ ), minerals, enzymes, carotenoids, and several phytochemicals (flavonoids, polyphenols, lycopene, lutein, terpenoid, and saponins) [82]. These raw vegetal compounds are vital natural nutrients due to their essential biochemical activities. They are used in food, pharmaceuticals, and cosmetic industries, where the consumption of these natural antioxidant compounds is thought to provide protection against oxidative damage and contribute to health benefits.

Eating a diet rich in natural products, such as vegetables, fruits, cereals, olive oil. and oats, can help to reduce or prevent cardiovascular diseases and some types of malignancy. The phenolic compounds are the major antioxidant components of these foods, which relate to their molecular structure (hydroxyl groups) and to double-bond conjugation impacts [83]. Furthermore, the vegetables and fruits contain high quantities of phenolic compounds with other phytochemical antioxidants and antimicrobial characterizations, which are capable of neutralizing free radicals and helping to reduce the risk of mortality of certain diseases such as coronary heart diseases, the incidence of myocardial infarction, cancer, diabetes, osteoporosis, and Alzheimer [84-88]. The vegetables and fruits can also provide important protective effects in cellular detoxification processes [89].

Antioxidants are molecules that can prevent the oxidation of proteins, carbohydrates, fats, and nucleic acids in organisms. Also, they act as the radical traps that protect tissues from free radicals that can cause illnesses. Various phenolic compounds possess high antioxidant activity, where the vegetables and fruits are a rich source 
of natural antioxidants and phenolic compounds [90]. Additionally, antioxidants have attracted considerable attention as potential compounds (RSA and TPC) that can prevent or delays oxidative-stress-related diseases, where it can balance or inhibit oxidation degradation of various substances by reducing oxygen content. This prevents chain initiation by scavenging premier radicals, such as hydroxyl radicals, and neutralizing them, and preventing certain diseases. Oxidation is a chemical reaction that can produce free radicals, thus leading to chain reactions that damage the cells of organisms [88, 91-92].

\subsubsection{Radical scavenging activity (RSA percent): Data} presented in Table 5 exposed that the supplemented cheese with the vegetables mixture gradually increased the RSA and TPC in the resultant FPC samples by increasing the percentage added. The RSA values of FPC were significantly higher compared to the control sample, due to the higher content of antioxidant components in the chosen vegetables. The obtained data of RSA values of FPC samples were high, being 9.33, $34.48,68.73,86.04$, and $106.23 \%$ for control, $F_{1}, F_{2}, F_{3}$, and $F_{4}$, respectively. Our results tend to agree with those reported $[26,44,93]$.

\subsubsection{Total phenolic compounds (TPC):}

Furthermore, as illustrated in the same Table 5, the TPC values take a similar trend for RSA in all these processed cheese samples, where it had significantly FPC samples compared to the control sample and gradually increased by increasing enriched added ratios of vegetables mixture, being 7.81, 114.01, 163.31, 199.12, and 238.95 (mg/100 g passed on GA) for control, $F_{1}, F_{2}, F_{3}$ and $F_{4}$ in order. Most of the total phenolic compounds of vegetables and fruits show antioxidant activity, which can inhibit the oxidative degradation of various substances by scavenging reactive types, including free radicals. It can be concluded that the antioxidant activity data was closely correlated with the total polyphenol compound. Our data has the same tendency by [93]. Phytochemicals are supported to reduce the expression of oxidation stress in the body due to its biochemical ability to reduce free radicals [94]. Other benefits of fruits and vegetables include glucosinolates diet [95] or dietary fiber [96]. Cheese has health-promoting properties associated with some immune functions in the body. Though, polyphenols and the lack of carotenoids play a chief role as antioxidants in the human body [97-98]. So, our main objective of this study was to develop an innovative product by mixing dried vegetables into processed cheese for better nutrition and health promoting principles such as antioxidants and other useful phytochemicals. We conclude that the antioxidant activity data were closely correlated with the total polyphenol compound.

In the nutrition world, mushrooms represent a vegetable, a healthy utilitarian sustenance and a source of valuable medicines $[99,100]$. Many types of mushrooms consumed are excellent sources of carbohydrates, proteins, fats, B-vitamins, phenols, organic acids, and trace elements [101-102]. These components have been established to be responsible for immunomodulatory, antimicrobial, antitumor, antihypertensive, hepatoprotective, and antioxidant activities [103-104].

In a recent study, the promotion of healthy vegetable products has coincided with a rise in consumers concerned with the health functional foods. Each type of vegetable contains a unique mixture of phytonutraceuticals that distinguishes it from the other. It is beneficial to humans in preventing or treating many diseases or improving physiological functioning. Where they are closely related to improving the digestive system and good vision and reduce the risk of chronic diseases (diabetes, and some cancer types), heart disease, and stroke [105]. 


\section{CONCLUSION}

Functional Food Scientists of the Functional Food Institute/Functional Food Center (FFC) are developing its current definition of functional foods to fit a more accurate and comprehensive idea of what functional foods do. The Food and Drug Administration (FDA) classified functional foods as a drug; however, FFC has proposed a new definition: "Natural or processed foods that contain biologically-active compounds, which, in defined, effective, non-toxic amounts, provide a clinically proven and documented health benefit utilizing specific biomarkers, to promote optimal health and reduce the risk of chronic/viral diseases and manage their symptoms" [106].

We produced a new dairy product as functional and healthy processed cheese using a mixture of various vegetables powders with functional and nutritional attributes. We concluded that the results have increased nutritional quality such as high amounts of vitamins, minerals, amino acids, and antioxidant compounds (RSA, TPA). These parameters have positively increased health promotion as functional foods of newly flavored products. Additionally, FPC samples have gained high acceptance and they satisfy the needs of all ages of children and adults. The fortified cheeses use different vegetables to provide a distinct taste, aroma, and flavor for better consumer acceptance. It also has many health benefits due to their high phenolic compounds and high antioxidant capacity. Our vegetable processed cheese product is a potential functional food, or a good candidate for a functional food that ensures the safety of administering bioactive compounds as a healthimproving tool.

Abbreviations: AA: amino acids, EAA: essential amino acids, FA: fatty acids, FPC: flavored-processed cheese, $F_{1}$ : formulation one with vegetables mixture $(2.5 \%), F_{2}$ : formulation two with vegetables mixture $(5 \%), F_{3}$ : formulation three with vegetables mixture $(7.5 \%), F_{4}$ : formulation four with vegetables mixture $(10 \%), \mathrm{NaCl}$ : sodium chloride, NEAA: non-essential amino acids, RSA: radical scavenging activity, SFA: saturated fatty acids, SN: soluble nitrogen, TPC: total phenolic compounds, USFA: un-saturated fatty acids.

Conflict of Interest: The authors declare that they have no conflicting interests.

Authors Contribution: All authors contributed towards all parts of the manuscript to the design, data acquisition, analysis, and interpretation, as well as participate in the drafting and revision of the article.

Authors Agreement: All authors have read and approved to submit this manuscript version and agree to take responsibility for all aspects of the study.

Human and Animal Participants: This article does not contain any studies with human or animal subjects.

Funding sources: There was no funding received for this study.

\section{REFERENCES}

1. Boomers (Part 1)-To your health: 2021. [https://www.theboomerexplorer.com/boomers-part-1-to-yourhealth/] Retrieved January 1, 2022.

2. Swensson $C$, Lindmark-Mansson $H$, Smedman A, Henriksson $M$, ModinEdman AK: Protein efficiency in intensive dairy production: A Swedish example. J Sci Food and Agric 2017, 97(14):4890-4897. hhtps://doi.org/10.1002/fsfa.8362

3. Rafiq SM, Ghosh BC: Effect of potato incorporation on the physicochemical, textural and sensory properties of processed cheese. J Food Meas and Charact. 2017, 11(2):776-780. https://doi.org/10.1007/s11694-016-9448-3

4. The nutrition source, vegetables and fruits [https://www.hsph.harvard.edu/nutritionsource/what-shouldyou-eat/vegetables-and-fruits/] Retrieved January 1, 2022. 
5. Ramya V, Patel P: Health benefits of vegetables. Int J Chem Studies 2019, 7(2):82-87.

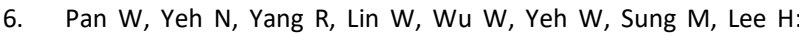
Vegetable, fruit, and phytonutrient consumption patterns in Taiwan. J Food and Drug Analysis 2018, 26(1):145-153. https://doi.org/10.1016/j.jfda.2016.12.0156

7. Arakelyan HS: Healthiest Vegetables-1. Green Peas. Project: Clinical Food Therapy, 2019.

8. Farahat ESA, Mohamed AG, El-Loly MM, Gafour WAMS: Innovative vegetables-processed cheese: I. Physicochemical, rheological and sensory characteristics. Food Biosci. 2021, 42:101128. https://doi.org/10.1016/j.fbio.2021.101128

9. Ayeka PA: Potential of mushroom compounds as immunomodulators in cancer immunotherapy - A Review. Evidence-Based Complem and Altern Med 2018, 1:1-9. https://doi.org/10.1155/2018/7271509

10. The 30 most nutritious vegetables that will make you feel energetic

[https://www.bustle.com/p/the-30-most-nutritious-vegetablesthat-will-make-you-feel-energetic-46569] Retrieved January 1, 2022.

11. Barros L, Cruz T, Baptista P, Estevinho LM, Ferreira ICFR: Wild and commercial mushrooms as source of nutrients and nutraceuticals. Food and Chem Toxic 2008, 46:2742-2747. https://doi.org/10.1016/j.fct.2008.04.030

12. Jahan A, Singh BK: Mushroom value chain and role of value addition. Int J Botany and Res 2019, 9(1):5-14.

13. Kaur R: Medicinal importance of mushroom. Asian J Hortic 2018, 13(2):64-67. https://doi.org/10.15740/has/tajh/13.2/64-67

14. Rathore H, Prasad S, Kapri M, Tiwari A, Sharma S: Medicinal importance of mushroom mycelium: Mechanisms and applications. J Funct Foods 2019, 56:182-193.

15. Khider M, Seoudi O, Abdelaliem YF: Functional processed cheese spreads with high nutritional value as supplemented with fresh and dried mushrooms. Int J Nutr and Food Sci 2017, 6(1):45-52.

16. Gizaw B, Tsegay Z, Tefera G, Aynalem E: Traditional knowledge on mushroom consumption habits of Amhara region in four selected districts - Mecha, Fogera, Bahir Dar zuria and Zege. Acad J Food Res 2018, 6(2):21-30.

https://doi.org/10.19080/jojha.2018.01.555552

17. Maa G, Yang W, Zhaoa J, Pei F, Fang D, Hu Q: A critical review on the health promoting effects of mushrooms nutraceuticals. Food Sci and Human Wellness 2018, 7(2):125-133. https://doi.org/10.1016/j.fshw.2018.05.002

18. Singh R: A review on different benefits of mushrooms. IOSR J. Pharm. and Biolog. Sci 2017, 12(1):107-111. https://doi.org/10.9790/3008-120102107111
19. Furrer AN, Chegeni M, Ferruzzi MG: Impact of potato processing on nutrients, phytochemicals and human health. Crit Rev Food Sci and Nutr 2017, 58(1):146-68.

https://doi.org/10.1080/10408398.2016.1139542

20. Thorning TK, Bertolt CJ, Nielsen MS, Ritz C, Astrup A, Raben A: Potato fibers have positive effects on subjective appetite sensations in healthy men, but not on fecal fat excretion: $A$ randomized controlled single-blind crossover trial. Nutrients 2020, 12:3496. https://doi.org/10.3390/nu12113496

21. What's to know about butternut squash? [https://www.medicalnewstoday.com/articles/284479.php] Retrieved January 1, 2022.

22. Perez-Gutierrez RM: Review of Cucurbita pepo (Pumpkin) its phytochemistry and pharmacology. Med Chem 2016, 6(1):12-21. https://doi.org/10.4172/2161-0444.1000316

23. Ahmad G, Khan AA: Pumpkin: Horticultural importance and its roles in various forms - a review. Int J Hortic and Agric 2019, 4(1):16.

24. Carrots 101: Nutrition Facts and Health Benefits [https://www.healthline.com/nutrition/foods/carrots\#benefits] Retrieved January 1, 2022.

25. Surbhi S, Verma RC, Deepak R, Jain HK, Yadav KK: A review: Food, chemical composition and utilization of carrot (Daucus carota L.) pomace. Int J Chem Studies 2018, 6(3):2921-2926.

26. Mohamed AG, Shalaby SM, Gafour WA: Quality characteristics and acceptability of an analogue processed spreadable cheese made with carrot Paste (Daucus carota L.). Int J Dairy Sci 2016, 11(3):91-99. https://doi.org/10.3923/ijds.2016.91.99

27. Hou D, Yousaf L, Xue Y, Hu J, Wu J, Hu X, Feng N, Shen Q: Mung pean (Vigna radiata L.): Bioactive polyphenols, polysaccharides, peptides, and health benefits. Nutrients 2019, 11(6):1238. https://doi.org/10.3390/nu11061238

28. Butnariu M, Butu A: Chemical Composition of Vegetables and Their Products. Handbook of Food Chemistry 2015:627-692. https://doi.org/10.1007/978-3-642-36605-5 17

29. Green beans: nutrition facts and health benefits [https://www.healthline.com/health/food-nutrition/greenbeans\#heart-health] Retrieved January 1, 2022.

30. Winham D, Webb D, Barr A: Beans and good health. Nutr. Today 2008, 43(5):201-209. https://doi.org/10.1097/01.nt.0000303354.21347.45

31. Green beans nutrition helps you fight cancer and improve digestion

[https:/www./draxe.com/nutrition/vegetables/green-beansnutrition/] Retrieved January 1, 2022. 
32. Why green peas are healthy and nutritious? [https://www.healthline.com/nutrition/green-peas-are-healthy] Retrieved January 1, 2022.

33. Qureshi K, Tabassum F, Amin NM, Akram MZ, Zafarm M: Investigation of Mineral Constituents of Apium graveolens L available in khyber pakhtunkhwa Pakistan. J Pharm and Phyto. 2014, 3(4):234-239.

34. Al-Snafi AE: Traditional uses of Iraqi medicinal plants. J Pharmacy 2018, 8(8):32-95.

35. Abd El-Rehem FA, Ali RF: Proximate compositions, phytochemical constituents, antioxidant activities and phenolic contents of seed and leaves extracts of Egyptian leek (Allium ampeloprasum var. kurrat). Eur J Chem 2013, 4(3):185-190. https://doi.org/10.5155/eurjchem.4.3.185-190.711

36. Mondy N, Duplat D, Christides JP, Arnault I, Auger J: Aroma analysis of fresh and preserved onions and leek by dual solidphase microextraction-liquid extraction and gas chromatographymass spectrometry. J Chromato A 2002, 963:89-93. https://doi.org/10.1016/s0021-9673(02)00221-2

37. Wahba NM, Ahmed AS, Ebraheim ZZ: Antimicrobial effects of pepper, parsley, and dill and their roles in the microbiological quality enhancement of traditional Egyptian kareish cheese. Foodborne Path and Dis 2010, 7(4):411-418. https://doi.org/10.1089/fpd.2009.0412

38. Li, Z.; Xue, Y.; Li, M.; Guo, Q.; Wang, S.Y.; Luo, C. The antioxidation of different fractions of dill (anethum graveolens) and their influences on cytokines in macrophages RAW264.7. J Oleo Sci 2018, 67(12):1535-1541.

39. Kreydiyyeh SI, Usta J, Kaouk I, Al-Sadi R: The mechanism underlying the laxative properties of parsley extract. Phytomed 2001, 8:382-388. https://doi.org/10.1078/0944-7113-00058

40. Wright $\mathrm{Cl}$, Van-Buren $\mathrm{L}$, Kroner $\mathrm{Cl}$, Koning $\mathrm{MM}$ : Herbal medicines as diuretics: a review of the scientific evidence. J Ethnopharm 2007, 114:1-31. https://doi.org/10.1016/j.jep.2007.07.023

41. Nashtar SB, Hashim I, Al-Attar Z: The effect of parsley in the treatment of UTI in Iraqi patients. Int J Med Res and Health Sci 2018, 7(8):1-7.

42. Bolkent S, Yanardag R, Ozsoy-Sacan O, Karabulut-Bulan O: Effects of parsley (Petroselinum crispum) on the liver of diabetic rats: $A$ morphological and biochemical study. Phytotherapy Res 2004, 18:996-999. https://doi.org/10.1002/ptr.1598

43. Jimenez-Alvarez D, Giuffrida F, Golay PA, Cotting C, Lardeau A, Keely BJ: Antioxidant activity of oregano, parsley, and olive mill wastewaters in bulk oils and oil-in-water emulsions enriched in fish oil. J Agric and Food Chem 2008, 56:7151-7159. https://doi.org/10.1021/jf801154r
44. El-Taweel HS, El-Sisi AS, Mailam MA: Improving functional properties of Kareish cheese by adding low sodium salt and dried parsley. Egypt J Agric Res 2017, 95(3):1179-1191. https://doi.org/10.21608/EJAR.2017.149646

45. Acimovic MG: Nutraceutical Potential of Apiaceae, 2019:13111341. In Bioactive Molecules in Food. Mérillon JM, Ramawat KG (eds), Springer Nature Switzerland.

46. Angelino D, Godos J, Ghelfi F, Tieri M, Titta L, Lafranconi A, Marventano S, Alonzo E, Gambera A, Sciacca S, Buscemi S, Ray S, Galvano F, Del Rio D, Grosso G: Fruit and vegetable consumption and health outcomes: an umbrella review of observational studies. Int J. Food Sci and Nutr 2019, 70(6):1-16. https://doi.org/10.1080/09637486.2019.1571021

47. Wurtz AM, Hansen MD, Tjønneland A, Rimm EB, Schmidt EB, Overvad K, Jakobsen MU: Replacement of potatoes with other vegetables and risk of myocardial infarction in the Danish Diet, Cancer and Health cohort. $\mathrm{Br} J$ Nutr 2021, 1-8. https://doi.org/10.1017/S0007114521000349

48. AOAC: Official Methods of Analysis. Association of the Official Analytical Chemists, $18^{\text {th }}$ ed, Washington, DC, USA, 2006.

49. Lucas A, Rock E, Chamba JF, Verdier-Metz I, Brachet P, Coulon JB: Respective effects of milk composition and cheese-making process on the cheese composition variability in components of nutritional interest. Lait 2006, 86:21-41. https://doi.org/10.1051/lait:2005042

50. Brand-Williams W, Cuvelier ME, Berset C: Use of a free radical method to evaluate antioxidant activity. LWT - Food Sci and Tech 1995, 28(1):25-30. $\quad$ https://doi.org/10.1016/s00236438(95)80008-5

51. Zheng W, Wang SY: Antioxidant activity and phenolic compounds in selected herbs. J Agric and Food Chem 2001, 49(11):5165-5170. https://doi.org/10.1021/jf010697n

52. SAS: Statistical analysis system. NC, USA: Statistical Analysis System Institute Inc, 2001.

53. Aune D, Giovannucci E, Boffetta P, Fadnes LT, Keum N, Norat T, Greenwood DC, Riboli E, Vatten $\amalg$, Tonstad S: Fruit and vegetable intake and the risk of cardiovascular disease, total cancer and allcause mortality-a systematic review and dose-response metaanalysis of prospective studies. Int J Epidemiol 2017, 46(3):10291056. https://doi.org/10.1093/ije/dyw319

54. Abd El-Razik MM, Mohamed AG: Utilization of acid casein curd enriched with Chlorella vulgaris biomass as substitute of egg in mayonnaise production. World Applied Sci J 2013, 26:917-925. https://doi.org/10.5829/idosi.wasj.2013.26.07.13523

55. Dragsted LO: Mushrooms and health. Am J Clin Nutr 2019, 10(3):546-547. https://doi.org/10.1093/ajen/nqz096 
56. Chioza A, Ohga S: Cultivated mushrooms in Malawi: A look at the present situation. Adv Microbio 2014, 4:6-11. https://doi.org/10.4236/aim.2014.41002

57. Sadler M: Nutritional properties of edible fungi. Nutr Bulletin 2003, 28(3):305-308. $\quad$ https://doi.org/10.1046/j.14673010.2003.00354.x

58. Vetter J: Biological values of cultivated mushrooms - A review. Acta Alimentaria 2019, 48(2):229-240. https://doi.org/10.1556/066.2019.48.2.11

59. Talbot-Walsh G, Kannar D, Selomulya C: A review on technological parameters and recent advances in the fortification of processed cheese. Trend Food Sci and Tech 2018, 81:193-202. https://doi.org/10.1016/j.tifs.2018.09.023

60. WHO: World Health Organization, Department of Nutrition for Health and Development (NHD), Switzerland, 2006.

61. Singh S, Devi MB: Vegetables as a potential source of nutraceuticals and phytochemicals - A review. Int J Med and Pharm Sci 2015, 5(2):1-14.

62. Wu G: Functional amino acids in growth, reproduction and health. Adv Nutr 2010, 1(1):31-37. https://doi.org/10.3945/an.110.1008

63. Mau J: The umami taste of edible and medicinal mushrooms. Int J Med Mushrooms 2005, 7(1/2):119-125. https://doi.org/10.1615/intjmedmushr.v7.i12.120

64. Kakon AJ, Choudhury BK, Saha S: Mushroom is an ideal food supplement. J Dhaka National Med College and Hospital 2012, 18(1):58-62. https://doi.org/10.3329/jdnmch.v18i1.12243

65. Rafiq SM, Ghosh BC: Effect of peanut addition on the fatty acid profile and rheological properties of processed cheese. J Food Proc and Tech 2017, 8:690-695. https://doi.org/10.4172/2157$\underline{7110.1000690}$

66. Petrovic J, Glamočlija J, Stojkovic D, Ciric A, Barros L, Ferreira IC, Sokovic M: Nutritional value, chemical composition, antioxidant activity and enrichment of cream cheese with chestnut mushroom Agrocybe aegerita (Brig.) Sing J Food Sci and Tech 2015, 52(10):6711-6718. https://doi.org/10.1007/s13197-015-1783-6

67. Borchers AT, Krishnamurthy A, Keen CL, Meyers FJ, Gershwin ME: The immunobiology of mushrooms. Exp Biology and Med (Maywood) 2008, 233(3):259-276. https://doi.org/10.3181/0708$\underline{\mathrm{mr}-227}$

68. Kurtzman RHJr: Mushrooms: Sources for modern western medicine. Micología Aplicada Int 2005, 17(2):21-33.

69. Ball G: Vitamins. Their Role in the Human Body. New York, Blackwell Publishing, 2004.

70. Lieberman S, Brunning N: Real Vitamin and Mineral Book. New York: Penguin Books, 2003.

71. Aslam MF, Majeed S, Aslam S, Irfan JA: Vitamins, key role players in boosting up immune response-a mini review. Vitamins and
Minerals 2017, 6:153. https://doi.org/10.4172/2376$\underline{1318.1000153}$

72. Borel P, Desmarchelier C: Bioavailability of fat-soluble vitamins and phytochemicals in humans: effects of genetic variation. Annual Rev Nutr 2018, 38:69-96.

https://doi.org/10.1146/annurev-nutr-082117-051628

73. Elliot JG: Application of antioxidant vitamins in foods and beverages. Food Tech 1999, 53:46-48.

74. Awad RA, Farahat AM, Salama WM: Production and in vivo nutritional evaluation of functional soft cheese supplemented with broccoli. World J Dairy and Food Sci 2012, 7(2):150-159.

75. IFICF (International Food Information Council Foundation): Potassium and heart health. [https://www.foodinsight.org] Retrieved January 1, 2022.

76. Suleiman TA, Mohamed OMA, El-Nissreen HM, Elsiddig MO: Chemical and microbiological evaluation of processed cheese available in Khartoum market, Sudan. Am J Food and Nutr 2011, 1(1):28-33. https://doi.org/10.5251/ajfn.2011.1.1.28.33

77. Yang $Q$, Liu T, Kuklina EV, Flanders WD, Hong Y, Gillespie C, Chang MH, Gwinn M, Dowling N, Khoury MJ, Hu FB: Sodium and potassium intake and mortality among US adults, prospective data from the third national health and nutrition examination survey. Archives Int Med 2011, 171(13):1183-1191. https://doi.org/10.1001/archinternmed.2011.257

78. Abd-Rabou FH, Abd El-Fattah AM, El-Sayed MM, Mohamed AG: Improvement of nutritional value of processed cheese by using modified emulsifying salts. Egypt J Dairy Sci 2005, 33:85-103.

79. Aberoumand A, Deokule SS: Determination of elements profile of some wild edible plants. Food Analy Meth 2009, 2:116-119.

80. Sajib MAM, Jahan S, Islam MZ, Khan TA, Saha BK: Nutritional evaluation and heavy metals content of selected tropical fruits in Bangladesh. Int Food Res J 2014, 21(2):609-615.

81. Arvanitidou V, Voskaki I, Tripsianis G, Athanasopoulou H, Tsalkidis A, Filippidis S, Schulpis K, Androulakis I: Serum copper and zinc concentrations in healthy children aged 3-14 years in Greece. Biological Trace Element Res 2007, 115:1-12. https://doi.org/10.1385/bter:115:1:1

82. Nahak G, Suar M, Sahu RK. Antioxidant potential and nutritional values of vegetables: A Review. Res J Med Plants 2014, 8(2):50-81. https://doi.org/10.3923/rjmp.2014.50.81

83. Rice-Evans CA, Miller NJ, Paganga G: Structure-antioxidant activity relationships of flavonoids and phenolic acids. Free Radical Biology and Med 1996, 20(7):933-938. https://doi.org/10.1016/0891-5849(95)02227-9

84. Kaur C, Kapoor HC: Antioxidants in fruits and vegetables-the millennium's health. Int J Food Sci and Techn 2001, 36:703-725. https://doi.org/10.1111/j.1365-2621.2001.00513.x 
85. Muthuswamy S, Rupasinghe HPV, Stratton GW: Antimicrobial effect of cinnamon bark extract on Escherichia coli 0157:H7, Listeria innocua and fresh-cut apple slices. J Food Safety 2008, 28:534-549. https://doi.org/10.1111/j.1745-4565.2008.00129.x

86. Pandey KB, Rizvi SI: Plant polyphenols as dietary antioxidants in human health and disease. Oxidative Med and Cell Long 2009, 2(5):270-278. http://doi.org/10.4161/oxim.2.5.9498

87. Tuchila C, Jianu I, Rujescu Cl, Butur M, Ahmadi-Khoie M, Negrea I: Evaluation of the antimicrobial activity of some plant extracts used as food additives. J Food Agric and Enviro 2008, 6(3, 4):6870.

88. Waltenberger B, Mocan A, Smejkal K, Heiss EH, Atanasov AG: Natural products to counteract the epidemic of cardiovascular and metabolic disorders. Molecules 2016, 21(6):807. https://doi.org/10.3390/molecules21060807

89. Wang SY: Fruits with High Antioxidant Activity as Functional Foods. 2007, pp: 370-413. In Functional Food Ingredients and Nutraceuticals - Processing Technologies. Shi, J (ed), Taylor and Francis Group, LLC, Boca Raton, London, New York.

90. Prvulovic D, Kolarov R, Tukuljac MP, Barac G, Dulic J, Miodragovic M, Ognjanov V: Antioxidant activity of wild-growing fruits from Western Serbia. VI Int. Congress “Engineering, Environment and Materials in Processing Industry“, 2019, pp: 350-355.

91. Khan IT, Nadeem M, Imran M, Ullah R, Ajmal M, Jaspal MH: Antioxidant properties of milk and dairy products: a comprehensive review of the current knowledge. Lipids Health and Dis 2019, 18(1):41. https://doi.org/10.1186/s12944-0190969-8

92. Flieger J, Flieger W, Baj J, Maciejewski R: Antioxidants Classification, Natural Sources, Activity/Capacity Measurements, and Usefulness for the Synthesis of Nanoparticles. Materials 2021, 14:4135. https://doi.org/10.3390/ma14154135

93. Kassem JM, Abbas HM, Mohamed AG, Bahgaat WK, El-Messery TM: Sweet processed cheese spread analogue as a novel healthy dairy product. Int J Dairy Sci 2017, 12(5):331-338. https://doi.org/10.3923/ijds.2017.331.338

94. Chu YF, Sun J, Wu X, Liu RH: Antioxidant and antiproliferative activities of common vegetables. J Agric and Food Chem 2002, 50(23):6910-6916. https://doi.org/10.1021/jf020665f

95. Heber D: Vegetables, fruits and phytoestrogens in the prevention of diseases. J Postgraduate Med. 2004, 50:145-149.

96. Fahey JW: Brassicas. In Caballero B, Trugo L, Fingla SP (eds) Encyclopedia of food science and nutrition. Academic, St Louis, 2003, pp:606-615.

97. O'Connell JE, Fox PF: Significance and applications of phenolic compounds in the production and quality of milk and dairy products - a review. Int Dairy J 2001, 11:103-120. https://doi.org/10.1016/s0958-6946(01)00033-4

98. Buttris J: Cheese dietary importance. In Caballero B, Trugo L, Fingla SP (eds) Encyclopedia of food science and nutrition. Academic, St Louis, 2003, pp: 1115-1118.

99. Pan H, Han Y, Huang J, Yu X, Jiao C, Yang X, Dhaliwal P, Xie Y, Yang BB: Purification and identification of a polysaccharide from medicinal mushroom Amauroderma rude with immunomodulatory activity and inhibitory effect on tumor growth. Oncotarget 2015, 6(19):17777-17791. https://doi.org/10.18632/oncotarget.4397

100. Rahman T, Choudhury M: Shiitake mushroom: A tool of medicine. Bangladesh J.Med. Biochem. 2013, 5(1):24-32. https://doi.org/10.3329/bjmb.v5i1.13428

101. Khatua S, Paul S, Acharya K: Mushroom as the potential source of new generation of antioxidant: A review. Res J Pharm and Tech 2013, 6(5):496-505.

102. Ruthes AC, Smiderle FR, lacomini M: Mushroom heteropolysaccharides: A review on their sources, structure and biological effects. Carbohydrate Polymers 2016, 136:358-375. https://doi.org/10.1016/j.carbpol.2015.08.061

103. Taofiq O, Calhelha RC, Heleno S, Barros L, Martins A, SantosBuelga C, Queiroz MJRP, Ferreira ICFR: The contribution of phenolic acids to the anti-inflammatory activity of mushrooms: Screening in phenolic extracts, individual parent molecules and synthesized glucuronated and methylated derivatives. Food Res Int 2015, 76:821-827. https://doi.org/10.1016/j.foodres.2015.07.044

104. Valverde ME, Hernandez-Perez T, Paredes-Lopez O: Edible mushrooms: Improving human health and promoting quality life. Int J Microbio 2015, 7:14. https://doi.org/10.1155/2015/376387

105. Kumar D, Kumar S, Bhadana NK, Singh B, Shekhar S: Vegetables: Source of adequate health benefits. Annals Horticult. 2020, 13(2):124-130.

106. Martirosyan D, Kanya H, Nadalet C: Can functional foods reduce the risk of disease? Advancement of functional food definition and steps to create functional food products. Functional Foods in Health and Disease 2021, 11(5):213-221. https://www.doi.org/10.31989/ffhd.v11i5.788 